DOI: 10.19085/journal.sijbpg021202

\title{
Financial inclusion and poverty alleviation: How to achieve the desired results
}

\author{
Dominic Phil \\ Universität Tübingen, Geschwister-Scholl-Platz, 72074 Tübingen, Germany.
}

OScholedge International Journal of Business Policy \& Governance (ISSN 2394-3351), Vol.02, Issue 12 (2015) pp4-6. Published by: Scholedge R\&D Center [www.theSCHOLEDGE.org] [Email: sijbpg@scholedge.org]

\begin{abstract}
Did you realize that there are more than 2.5 billion individuals with no ledgers on the planet, and the majority of them are in Asia? Also, under one quarter of the world's 2.4 billion poor have a financial balance. Dealing with their cash utilizing formal money related administrations - investment accounts, advances, protection, and settlements - is a magnificent, unpleasant, incomprehensible dream for some, numerous families.
\end{abstract}

Keywords: Financial inclusion, poverty alleviation, access to finance

\section{Discussion}

On the off chance that so few individuals are incorporated into formal budgetary frameworks, what has changed and why are we more hopeful about enhancing access to back for poor people? What are ADB and other advancement accomplices doing about it? Lastly however above all, by what means would you be able to offer assistance?

There are three reasons why we can be confident. To start with, we know significantly more about poor people and their cash. Stuart Rutherford in his great book called Portfolios of the Poor reminds us by his exploration that the poor live rich expanded monetary lives, generally utilizing casual fund. They get and spare with neighbors, send cash home to the town, take progresses on wages, leave cash with others to forestall utilizing it for prompt requests, protect one another. What's more, the vast majority of these individuals don't have admittance to formal administrations. A lady in Bangladesh in his book says, "Unless you deal with your cash, you can't deal with your life."

Second, we know significantly more about the relationship in the middle of cash and neediness. The examination unmistakably demonstrates that in spots where there are more fluctuated money related administrations that achieve more individuals, economies become quicker. Everybody gets wealthier, and (decent astound) the poor turn out to be less poor somewhat speedier. Monetary development is more comprehensive, and more families advantage, when money works for poor people.

Since we know more, we can accomplish more. The Group of 20, or $\mathrm{G} 20$, is a gathering of fund priests and national bank governors from 19 of the world's biggest economies and the 
European Union. Their order is to advance development and financial improvement over the globe. In 2010 the G20 set up a key project for overall monetary consideration, complete with an arrangement of nine Principles, an Action Plan, and a Global Partnership with genuine cash and instruments. India's national bank set up and is executing a monetary incorporation procedure. So did the national bank in the UK, and in Nigeria. Thailand is pushing forward on this procedure with ADB support. From Armenia to Zambia, countries are attempting to enhance monetary administrations for their kin.

Different associations additionally assume basic parts, and here are a few samples. The Alliance for Financial Inclusion has 100 national banks overall chipping away at the issue cooperatively. The International Labor Organization has made over 10 years of genuine contrast acquainting microinsurance with the poor everywhere throughout the world. The Consultative Group to Assist the Poor (CGAP) - an essential research organization throughout the previous fifteen years - has extended monetary consideration choices and interest in versatile managing an account and other bleeding edge territories. The ADB has given over $\$ 2.6$ billion to microfinance and monetary consideration to its creating nation individuals. The World Bank has a worldwide database - Findex — indicating where the crevices are.

Innovation is offering us some assistance with improving access, especially with something many refer to as portable managing an account. In the Philippines individuals without a ledger can open an electronic cash "wallet" for all intents and purposes in their PDA. They can put in cash, take it out, send cash, make installments, all by messaging on their cell telephone and working with versatile keeping money operators in little stores all over. Versatile keeping money is secure, people groups oversee cash, and gives them access. Banks and insurance agencies are beginning to give extra administrations to these customers by utilizing operators. Portable managing an account is currently across the board in nations, for example, Brazil and Kenya, even in the most secluded zones. In Kenya there are significantly a greater number of individuals with versatile cash wallets than individuals with financial balances.

On the off chance that you are monetarily included, you can be swindled. Microfinance associations have driven the world in capable money, guaranteeing each customer has clear and justifiable data about each item and that they make free, educated decisions. Customers have approaches to gripe and get issues tended to. They can take in more about how to utilize money related administrations to engage them. Associations consent to be completely straightforward about all that they do. Accion drives an overall willful framework called the SMART battle that associations select in and vow to maintain these standards. Also, they pay the expenses to convey and be evaluated to demonstrate it. Don't we all wish our own banks and insurance agencies did likewise?

Third, what would you be able to do to guarantee individuals can take part in an extensive variety of reasonable, justifiable, valuable money related administrations? The most critical thing is that you are perusing this. You are advising yourself and attempting to get it. You can likewise read - there are some awesome assets, CGAP has center notes of one to five pages on a wide assortment of subjects so they can likewise offer assistance. Simply Google them. 


\section{Conclusion}

You can put access to back into your own specific manners of pondering your work and your life. How would you utilize monetary administrations? By what means will individuals physically pay for the power or clean water supply you are producing? Can it be made less demanding? At the point when a street is being constructed would you be able to help specialists recovery to take cash home to contribute? Will you guarantee they are protected against harm? Can you incorporate budgetary instruction in the educational modules of the training or social security work you are doing? Can you purchase or offer to individuals utilizing versatile cash? Will you give your time or your cash to offer assistance? Can you support those you work with to better comprehend this theme and impart to others? Make individuals without access to fund genuine and you can find ways to make a difference for them.

\section{References}

Beck, T., \& Demirguc-Kunt, A. (2006). Small and medium-size enterprises: Access to finance as a growth constraint. Journal of Banking \& Finance,30(11), 2931-2943.

Brealey, R. A. (2012). Principles of corporate finance. Tata McGraw-Hill Education.

Cornell, B., \& Shapiro, A. C. (1987). Corporate stakeholders and corporate finance. Financial management, 5-14.

Davis, K., Schoenbaum, S. C., \& Audet, A. M. (2005). A 2020 vision of patient-centered primary care. Journal of general internal medicine, 20(10), 953-957.

De Meza, D. (2002). Overlending?. The Economic Journal, 112(477), F17-F31.

Force, U. T., \& Rogers, R. G. (1999). Towards an urban renaissance. London: Spon.

Hughes, N., \& Lonie, S. (2007). M-PESA: mobile money for the "unbanked" turning cellphones into 24-hour tellers in Kenya. Innovations, 2(1-2), 63-81.

Rodrik, D., \& Subramanian, A. (2009). Why did financial globalization disappoint?. IMF staff papers, 56(1), 112-138.

Zeller, M., \& Sharma, M. (1998). Rural finance and poverty alleviation (No. 8). International Food Policy Research Institute (IFPRI). 